\title{
LEADERSHIP OF MALACCA SULTANATE RULERS IN ESTABLISHING DIPLOMATIC RELATIONS
}

\section{(Kepemimpinan Pemerintah Kesultanan Melayu dalam Menjalinkan Hubungan Diplomatik)}

\author{
Salmah Jan Noor Muhammad \\ salmahjan@upm.edu.my \\ Malay Language Department, \\ Faculty of Modern Language and Communication, \\ Universiti Putra Malaysia, Malaysia.
}

\begin{abstract}
Leadership is the ability of a government in shaping the people's mind to achieve goals that have been planned together in order to strengthen its administration especially in establishing diplomatic relations with other countries. Without the mobilization of intellectual and physical cooperation from these two groups, it is impossible for a government to succeed in its diplomatic missions. Therefore, this article will discuss the leadership of the Malay sultanate in establishing diplomatic relations through data analysis of the events described in historiographic manuscripts such as Sulalat alSalatin, Al-Tarikh Salasilah Negeri Kedah, Hikayat Merong Mahawangsa and Tuhfat al-Nafis. In addition, this article also describes the effectiveness of this leadership in response to the diplomatic relations that had been initiated by and accepted from other governments. The result of the study will show that a variety of methods or approaches were used by the rulers of the Malay sultanate in advancing the government's reputation from the economic, social and physical aspects.
\end{abstract}

Keywords: leadership, leaders/rulers, Malay sultanate, diplomatic, historiography 


\section{Abstrak}

Kepemimpinan merupakan upaya pemerintah dalam usaha membentukjiwa dan minda rakyat untuk bersama-sama merealisasikan matlamat yang telah direncanakan bagi memantapkan tadbir urus kerajaan, khususnya, dalam usaha menjalinkan hubungan diplomatik dengan kerajaan lain. Tanpa penggemblengan daya fikir dan fizikal daripada dua golongan ini, adalah mustahil untuk sesebuah kerajaan itu berjaya dalam misi diplomatiknya. Oleh itu, makalah ini akan membincangkan kepemimpinan pemerintah kesultanan Melayu dalam hubungan diplomatik dengan menggunakan kaedah analisis data terhadap peristiwa yang terdapat dalam naskhah historiografi seperti Sulalat al- Salatin, Al-Tarikh Salasilah Negeri Kedah, Hikayat Merong Mahawangsa dan Tuhfat al-Nafis. Selain itu, tulisan ini juga menghuraikan keberkesanan kepemimpinan tersebut terhadap hubungan diplomatik yang ditawarkan dan diterima daripada kerajaan luar. Dapatan menunjukkan bahawa terdapat pelbagai kaedah kepemimpinan yang digunakan oleh pemerintah kesultanan Melayu untuk melonjakkan nama kerajaan yang diperintah dari aspek ekonomi, sosial dan fizikal.

Kata kunci: kepemimpinan, pemerintah, kesultanan Melayu, diplomatik, historiografi

\section{INTRODUCTION}

Generally, leadership in diplomatic relations is a process of influence and influencing between a government's leaders and the people in order to achieve diplomatic goals that have been planned to strengthen the administration and governance of a country. In the feudal system, a leader is one who influences and the people are those who obey and carry out orders. The process of influencing and doing something voluntarily will take place when a leader succeeds in interpreting the planned goals into interaction and behaviour. According to Abdullah and Ainon (2005), leadership is behaviour aimed at influencing others so that they are willing and will voluntarily do what is required by the leader. Northouse (1997) states that leadership means all the activities that influence an individual in a group or organization and can bring about the achievement of a goal. Edmond (1979) is of the opinion that this situation is a situation of "principals can make a difference", meaning an organization can be developed and its development originates from the leadership of the management. The ability to foster cooperation between the management and the workers in various activities of the organization is the important prerequisite for effective leadership. 
Diplomatic relations is a relationship arranged between governments and forms the basic structure for relations between countries using wisdom and diplomacy in official matters between nations (Mokhtar, 2005, p. 18). Apart from that, diplomatic relations is defined as relations between two or more governments that have the goal and desire to unite in filling a void which exists in the administration of a government (Salmah, 2015, p. 136). In other words, diplomatic relations is also the international relationship arising from collaboration between two or more governments in order to achieve similar goals. Therefore, leadership in diplomatic relations can be defined as the style or manner, interaction or behaviour of a leader in the effort to influence leaders of other nations in fostering or maintaining relations to achieve cooperation and create a win-win situation. To discuss the leadership of the Malay sultanate in fostering diplomatic relations, it is appropriate to study old Malay manuscripts, in particular the historiographic literature which will serve as suitable material for discussion. This genre is suitable because it provides clear evidence and clarification. Although this genre is sometimes clouded with mythical elements, this aesthetic feature does not obscure the events which the author wanted to convey. Some of the manuscripts which will be used as material for discussion are: Sulalat al-Salatin, Al-Tarikh Salasilah Negeri Kedah, Hikayat Merong Mahawangsa and Tuhfat al-Nafis. The selection of these manuscripts is suitable for the topic under discussion. Sulalat al-Salatin is a manuscript that describes the grandeur of the Malaccan government, while Al-Tarikh Salasilah Negeri Kedah and Hikayat Merong Mahawangsa focus on Kedah, and Tuhfat alNafis manuscript revolves around Johor-Riau and Lingga.

These manuscripts have often been used as reference in many types of research. For example, a study on Sulalat al-Salatin was done by AbdurRahman Mohamed Amin in 2015, the topic being "Sayings of Prophet Muhammad in Sulalat Us-Salatin". In the same year, Mahani (2015) conducted a study based on Al-Tarikh Salasilah Negeri Kedah as part of her research. The study is entitled "The Memory of The World Register: The Sultan Abdul Hamid Correspondence and Kedah History". In 2015, the topic of study was "Adaptasi Teks Hikayat Merong Mahawangsa kepada Filem: Analisis Perbandingan Unsur Naratif” (Film Adaptation of Hikayat Merong Mahawangsa: Comparative Analysis of Narrative Elements) by Mohamed Nazreen and Md. Salleh and Arbai'yah's topic of research was "Menelusuri Nilai Etika dalam Pemerintahan Johor-Riau-Lingga menerusi naskhah Tuhfat al- Nafis Versi Terengganu (Investigating Ethical Values in 
the Administration of Johor-Riau-Lingga through Tuhfat Al Nafis Terengganu version). The enthusiastic studies conducted onto these manuscripts have allowed this writer to delve into the topic of leadership of the Malay sultanate in fostering diplomatic relations between governments. This is because it is an important topic in the development and strengthening of the administration and influence of the governments of Malacca and Kedah during those times.

\section{OBJECTIVES}

The objective of this paper is to identify the methods used by the leadership of the Malay sultanate in fostering diplomatic relations from selected manuscripts, and analyze the effectiveness of these methods on the government in carrying out and strengthening diplomatic relations.

\section{METHODOLOGY}

In this paper, the qualitative method of text content analysis is used to identify the type of leadership in the context of diplomatic relations in the manuscripts Sulalat al-Salatin, Al-Tarikh Salasilah Negeri Kedah, Hikayat Merong Mahawangsa and Tuhfatal-Nafis. The effectiveness of these methods on the governments in carrying out and strengthening diplomatic relations will also be dealt with. There are three levels of research procedure in presenting this paper: collection of data, data analysis and summary. At the level of data collection, the writer will identify the Malay manuscripts that will suit the objective of this study. Every reading of the manuscript will be scrutinized and recorded, especially information that discusses the topic of the study. At the level of data analysis, the focus is on information acquired from the first level and will be used as material for discussion in analyzing the results of the study. From the results of the data analysis, a summary will be made to describe the Malay sultanate leadership in fostering diplomatic relations among nations.

\section{ANALYSIS AND DISCUSSION}

In this discussion, the writer will focus on the method of leadership used by the leaders in carrying out diplomatic relations. Among the methods used are: (a) sending a government representative of high calibre; (b) cultivating 
cooperation with two governments simultaneously; (c) encouraging familial ties based on the two-in-one method; and (d) devising a crafty plan.

\section{SENDING A HIGH-CALIBRE GOVERNMENT REPRESENTATIVE}

It is narrated in Sulalat al-Salatin, that Sultan Mansur Syah was a Malacca sultan who favoured diplomatic relations to strengthen the Malaccan government. Even before his reign however, Malacca was already a stable government, that is during the reign of Sultan Muhammad Syah, as narrated in Sulalat al-Salatin:

The narrator said: During his reign, Sultan Muhammad Syah was very fair in his dealings with everyone. Therefore Malacca grew and prospered, and the territory under its rule expanded. Westward it extended to Beruas Ujung Karang, eastward it stretched to Terengganu. Malacca's reputation spread to other countries from below the wind to above the wind, that Malacca was big and prosperous. Thus, traders came from all sides to Malacca (A. Samad Ahmad, 2010, p. 80).

However, the expansion of diplomatic relations would help Malacca to be in a stable position in terms of the economy, culture, physical aspect and religion. During the reign of Sultan Mansur Syah, Malacca succeeded in establishing diplomatic relations with Siam, which according to the author, was a nation that attempted many times to control Malacca but was not successful. Due to these unsuccessful attempts, the relations between Siam and Malacca became distant. Apart from that, Malacca also succeeded in establishing relations with China which was a superior power. This amounted to an acknowledgment of Malacca's status since a superior power had agreed to establish relations with it. According to Mohd Yusoff (1992), the effect of this relationship was that Malacca became a centre of political power without interference from other nations.

Malacca's success was also due to its high-calibre envoys. The rulers of Malacca placed great importance on the careful selection of suitable representatives or envoys. This is because a government's envoy is a reflection of the government's leadership. The envoy's success in carrying out the mission of the government would give a positive impact on the leadership of the Malacca Sultanate. According to Gallop (1994, p. 104), the success of a proficient envoy is being able to present in a subtle manner, his government's reputation and importance and at the same time avoid hurting the feelings 
of the host country. Every word that he utters carries some significance in bringing about success or failure of the diplomatic relations between governments. Hence, the failure of the envoy in carrying out his task will bring shame to himself and his government and the good name of the sultan. Such was the importance of sending envoys during the Malacca Sultanate. Nuruddin al-Raniri in Bustan al-Salatin laid down guidelines for rulers on how to select a suitable envoy:

The learned said, there are ten conditions for an envoy. The first condition, he must fear Allah SWT and be steadfast in religion. The second condition is he must be knowledgeable. The third condition, he must be attractive or presentable. The fourth condition, he must be trustworthy and not betray his king because of his own desires. The fifth condition, he must be eloquent and have a pleasant speaking voice, the sixth condition, he must be wise. The seventh condition, the envoy must be courageous in carrying out the king's instructions. The eight condition, he must be of good behaviour and smart. The ninth condition, he must be generous and noble. The tenth condition, he must not be greedy, if he is, his king's name will be tarnished (Jelani, 2009, pp. 275-279)

According to Jelani (2003, p. 182 ), the section on envoys presented in this manuscript is to show the king how important it is to select a suitable candidate, who is honest and responsible to act as an ambassador who will enhance the king and country's reputation. Hence, the right choice is the catalyst for diplomatic relations which will help the king convey his intentions correctly as well as enhance and strengthen diplomatic relations with other countries. Having guidelines on the selection of a country's envoy as laid down by Nuruddin al Raniri would help the king choose the most qualified candidate who can deal with regional governments.

The author of Sulalat as-Salatin listed the names of several envoys from Malacca who were sent to foreign countries to establish diplomatic relations during the reign of Sultan Mansur Syah. These include: (a) Seri Bija Pikrama, (b) Tun Sura Diraja, (c) Tun Telanai, (d) Menteri Jana Putra, (e) Tun Bijaya Sura, (f) Hang Tuah and (g) Tun Perpatih Putih. Seri Bija Pikrama and Tun Sura Diraja were sent to Sulawesi and Tun Telanai with Menteri Jana Putera were sent to Siam. Meanwhile, Tun Bijaya Sura and Hang Tuah were sent to Majapahit and the Malaccan envoy to China was Tun Perpatih Putih. The following table is a summary of Malacca's envoys to several governments in its diplomatic relations. 
Table 1: Malacca envoy and diplomatic government.

\begin{tabular}{|l|l|l|l|}
\hline No. & \multicolumn{1}{|c|}{ Malacca Envoy } & \multicolumn{1}{c|}{ Escort } & Diplomatic Government \\
\hline 1. & Seri Bija Pikrama & Tun Sura Diraja & Sulawesi (Mengkasar) \\
\hline 2. & Tun Telanai & Menteri Jana Putera & Siam \\
\hline 3. & Tun Bijaya Sura & Hang Tuah & Majapahit \\
\hline 4. & Tun Perpatih Putih & - & China \\
\hline
\end{tabular}

Normally, the envoy who was sent was a member of a noble family at court. For example, Tun Telanai was the son of Bendahara Paduka Raja (A. Samad Ahmad, 2010). Close ties with the palace was one of the factors that drove an envoy to help realize his king's ambitions. Apart from that, the envoy who was selected would work hard to ensure that the goals of the Malaccan government were achieved. This is because they were representatives of the government's leadership. Their behaviour and words reflected those of their leaders. In this section, only the events related to those envoys sent to Sulawesi and China will be dealt with. Some of the challenges faced by the appointed envoys and the implementation of their missions are described below:

\section{Diplomatic Governments: Malacca and Sulawesi (Mengkasar)}

(a) Envoy: Seri Bijaya Pikrama and Tun Sura Diraja leave for Sulawesi (Mengkasar)

Sebermula adalah pada suatu hari, Sultan Mansur Syah fikir hendak mengutus ke Mengkasar, maka memanggil Bendahara Paduka Raja datang mengadap, maka titah baginda, "Hamba hendak mengutus ke Mengkasar. Bagaimana kepada Bendahara, baiknya atau jahatnya?" Maka sembah Bendahara, "Sebaik-baik pekerjaan tuanku, berbanyak-banyak sahabat daripada seteru."

$$
\text { (A. Samad Ahmad, 2010, p. 100) }
$$

[One day, Sultan Mansur Syah decides to send an envoy to Mengkasar, therefore he calls Bendahara Paduka Raja for an audience with him, and he decrees: I would like to send an envoy to Mengkasar. What is your opinion on this? Good or bad? Bendahara replies "Of all the good deeds your majesty, is to make more friends than enemies"] 
(b) Challenges: This initiative did not encounter any challenges

Maka titah raja di Goa, "Hei Orang Kaya, apa khabar saudaraku di Melaka, tiada ia sakit-sakit? Dan apa kehendaknya menyuruhkan Orang Kaya kedua ini, apa hendak dicari?" Maka sahut Seri Bija Pikrama, "Khabar baik keraeng. Tidak apa kehendak paduka adinda menyuruh mengadap tuanku, sekadar hendak muafakat juga. keraeng." Maka raja di Goa pun terlalu suka, seraya katanya, "Aku pun demikian lagi Orang Kaya, hendak muafakat dengan saudaraku raja Melaka."

(A. Samad Ahmad, 2010, p. 101)

[So the king in Goa responds: "Hey, Orang Kaya, how is my friend in Malacca, is he well? What is his intent in sending the second Orang Kaya, what is he looking for?" Then Seri Bija Pikrama replies: "He is well, O King. Nothing in particular but I was asked to have an audience with you, to offer my cooperation in any way, O King". The king in Goa was very pleased, and said: "I too wish the same thing, Orang Kaya, to collaborate with my friend the sultan of Malacca".]

\section{(c) Method of Implementation}

Memohon seorang budak yang berketurunan baik untuk dijadikan hamba raja Melaka. Permohonan tersebut dipersetujui oleh raja Goa. Lalu baginda telah menghadiahkan anak raja Bajung yang bernama Daeng Mempawah. Maka sembah Seri Bija Pikrama, "Tuanku, yang kegemaran paduka adinda itu, jikalau ada budak laki-laki yang baik rupanya dan sikap serta dengan beraninya, itulah yang kegemaran paduka adinda." Maka titah raja di Goa, "Budak budak bagaimana itu? Anak orang baikkah? Atau sebarang orangkah?"Maka sembah Seri Bija Pikrama, "Jikalau boleh, anak oang baiklah, keraeng." Setelah baginda mendengar kata Seri Bija Pikrama itu, maka titah raja di Goa kepada juak-juaknya, "Pergi engkau semua carikan aku, anak daeng baik, anak hulubalang baik; Parang yang baik rupanya dan sikapnya engkau ambil."

(A. Samad Ahmad, 2010, p. 103)

[Request for a boy of good birth to become a servant of the sultan of Malacca. This was granted by the Goa king and he offered the prince of Bajung by the name of Daeng Mempawah. Then Seri Bija Pikrama said, "Your majesty, my king is fond of a boy who is good looking and of fine behaviour as well as brave, that is the type he is fond of". The king of Goa replied: "What type should the boy be? Someone of noble birth? Or a commoner?" Seri Bija 
Pikrama replied: "If possible, a boy of noble birth". When the king of Goa heard what Seri Bija Pikrama said, he ordered his servants: "Go and find for me a good son of a Daeng, a good son of a soldier. Look for someone who has fine looks and character".]

\section{The Diplomatic Governments of Malacca and China}

a) Envoy: Tun Perpatih Putih

The main motive of the Malaccan government in sending Tun Perpatih Putih to China was to reciprocate the emperor of China's gift of needles stacked in a boat as well as letters. The present symbolized the greatness of China with its huge number of people. The sultan of Malacca reciprocated by sending a boat full of sago.

(b) Challenges

When Tun Perpatih Putih was in China, he faced an intellectual test. The emperor of China spontaneously asked him questions incessantly. The questions put forth by the emperor were:

Setelah diketahuinyalah ertinya, maka terlalulah sukacita raja China mendengar dia, dan sagu pun dibawa oranglah, ke hadapan raja. Maka titah raja China pada Tun Perpatih Putih, "Bagaimana membuat dia ini?"

(A. Samad Ahmad, 2010, p. 132)

[When he found out the meaning, the emperor was pleased and the sago was brought to him. Then the emperor asked Tun Perpatih Putih: "How is this made?']

Maka titah raja China kepada Tun Perpatih Putih, "Apa kegemaran orang Melaka?"

(A. Samad Ahmad, 2010, p. 133)

[Then the emperor asked Tun Perpatih Putih "What are the people of Malacca fond of?"]

These questions required that the envoy is aware of the situation he faces. Innately, it symbolizes a leadership that is always prepared to face challenges in his government. This is because if the envoy who represents 
the ruler is not prepared, it is certain that he will not be in a stable position, under pressure and unable to answer questions put to him. Failure to answer questions means the envoy failed to carry out his responsibility and this will tarnish his image and that of his government's capability. According to Mohd Azhar (2004, p. 117), the mind can work or be in conflict with what man wants. In a passive state and under stress, a human being will become a victim to pressures and if a person is able to manage these pressures, then he can avoid stress. Therefore, a positive state of mind is an alternative method to manage the pressures being faced.

\section{(c) Method of Implementation}

According to Abu Hassan (2001, p. 179), the intellectual characteristic of a person can be seen in the creative thinking process and also the rationalization of ideas and arguments which can be supported by reasons in looking for answers or solving problems. Abu Hassan's views are represented exactly in the method of implementation by Tun Perpatih Putih. He answered without hesitation every question put to him by the emperor of China. For example:

Maka sembah Tun Perpatih Putih, "Digelek tuanku, pada seorang sebiji disuruhkan oleh raja kami pada seorang rakyat, hingga sarat sebuah pilau; demikianlah banyak rakyat kami, tiada seorang pun tahu akan bilangannya." Maka titah raja China, "Besar raja Melaka itu, banyak sungguh rakyatnya, tiada berapa bezanya dengan rakyat kita. Baiklah ia kuambil akan menantuku."

(A. Samad Ahmad, 2010, p. 132)

[Tun Perpatih Putih answered (in reply to the emperor's query), "The king ordered each grain to be crushed by a single person until the whole boat is filled (with sago). So that is how many people we have, so much so no one knows the real number". Then the Chinese emperor said, "The sultan of Malacca must be a great king to have so many people, not very different from ours. I might as well take him as my son-in-law"]

Maka sembah Tun Perpatih Putih, "Sayur kangkung tuanku, jangan dikeratkerat, belah panjang-panjang, iaitulah kegemaran kami semua orang Melaka makan, tuanku." Maka disuruh oleh raja China sayurkan kangkung, seperti yang dikatakan oleh Tun Perpatih Putih itu. Setelah sudah masak, dihantarkan di hadapan Tun Perpatih Putih; dan orang Melaka sekaliannya pun membibit hujung sayur kangkung itu, serta menengadah, mengangakan mulutnya. 
Maka kelihatanlah raja China duduk di atas kerusi dalam mulut naga pada mungkar kacanya.

[Then Tun Perpatih Putih said to the emperor, "Your Majesty, please do not cut the water spinach into small pieces, let them be long, that is how we in Malacca like to eat." Therefore the emperor ordered that the water spinach be cooked as requested by Tun Perpatih Putih. When it was cooked, the water spinach was presented to Tun Perpatih Putih and the Malaccans held the ends of the vegetable to eat, tilted their heads, and opened their mouths. In doing so, they were able to get a glimpse of the emperor of China who sat on a throne in the mouth of a dragon made of glass.]

The Chinese emperor was totally convinced by the answer given by Tun Perpatih Putih. Clearly, Tun Perpatih Putih was a dynamic and effective communicator. A person who has self-confidence will achieve what he desires and will deliver a good presentation As a result, the emperor of China sent his princess, Hang Liu to be wedded to the sultan of Malacca so as to strengthen diplomatic ties between the two governments.

\section{CULTIVATING COOPERATION WITH TWO GOVERNMENTS SIMULTANEOUSLY}

Normally, this style of diplomatic leadership is used by a newly established nation as a way of introducing itself to expand its diplomatic relations and bring about cooperation between governments although the administration, religious belief and culture differ. The author of Hikayat Merong Mahawangsa narrates: the Langkasuka government planned to establish diplomatic relations with two governments simultaneously in its effort to spread diplomatic relations between governments. Raja Merong Mahawangsa, the king of Langkasuka planned to establish diplomatic relations with Aceh and Kelinngi in order to form a variety of diplomatic relations with both governments. The relationship between the governments of Langkasuka and Kelinggi was aimed at social diplomatic relations whereas the one with Aceh was more of a sociopolitical and socioeconomic relationship. The aims of Raja Merong Mahawangsa in establishing a variety of diplomatic relations were:

(a) to introduce the government of Langkasuka as a new government;

(b) to strengthen social ties through marriages and birth of intelligent 
children as a result of mixed marriages;

(c) to strengthen and fortify the defence system of the government. This is to prevent Langkasuka which was a new nation from being colonized by other big powers; and

(d) to accelerate economic activities and trading transactions based on shared property and trade.

Raja Merong Mahawangsa's leadership as a wise ruler is clearly seen when he was able to establish the direction of diplomatic relations for later generations' happiness and well being. According to Jelani (2003, p. 157), the king should be wise in governing the country and his people. A wise king can think rationally and is able to control his desires, have good judgment, and is careful in solving problems. Apart from that, in the manuscript Nasihat al-Muluk is described what a wise leader is like. For example:

Seyogianya bagi yang berkehendak akan memeliharakan adil atas segala rakyatnya itu bahawa ditertibkan akan segala hambanya dan pada segala yang bekerja padanya bagi adil itu. Dan peliharakan segala hal yang dikerjakan dan dilihat dalamnya seperti dilihat pada isi rumahnya, dan segala anaknya, dan segala tempatnya. Dan demikian itu bahawa jangan dikeraskan syahwatnya dan kusarnya atas akalnya itu. Dan jangan dijadikan akan akalnya dan agamanya itu akan tuannya syahwatnya dan kusarnya.

(Nasihat al-Muluk, MS Dc.6. 73-74:128)

[As was appropriate, to mete out justice fairly among the people, he maintained order on his servants and all those who worked for him. And he maintained order on what went on as if he was looking after his own household and children. Hence do not allow one's desires and anger to overpower one's thinking. And do not allow these desires and anger to be above one's mind and religion.]

Discoveries have shown that the goal of establishing diplomatic relations was realized when both governments agreed to receive each other's diplomatic missions initiated by Raja Merong. Below are citations that point towards the the acceptance of this diplomatic exchange:

First citation: Raja Kelinggi agrees to fulfil Raja Merong's request by giving him a large water jar: 
Maka titah raja Kelinggi, "Baiklah, jika demikian, adalah sebiji tempayan yang besar daripada orang tua hamba. Itulah hamba berikan pada raja tuan hamba." Lalu disuruh oleh raja Kelinggi ambil tempayan itu.

(Siti Hawa, 1998, p. 31)

[Raja Kelinggi said, "All right, if so, this is a large water jar that belonged to my parents. I give this to your king". Hence Raja Kelinggi ordered the water jar to be taken away.]

Second citation: Raja Kelinggi replied to Raja Merong's letter:

... Setelah sudah dimuat tempayan itu ke kapal, maka beberapa hari lamanya raja Kelinggi pun memberi surat balas kepada Raja Merong Mahawangsa itu, tanda berkasih-kasihan. Maka titah raja Kelinggi kepada utusan itu, "Katakanlah kepada raja tuan hamba, hendaklah disuruh orang pergi datang ke negeri beta ini, jangan berputusan, biar sampai kepada anak cucu"

(Siti Hawa, 1998, p. 32)

[... Having loaded the water jar onto the ship, after several days raja Kelinggi replied to Raja Merong, declaring his affection. Then raja Kelinngi said to the emissary, "Tell your king, let your people come and go into my country, for now and for all future generations." ]

Meanwhile, the mission to Aceh also received a positive response, when the emissary sent by Raja Merong brought back a letter and gifts from the ruler of Aceh. The evidence:

Sebermula maka adapun utusan yang disuruh pergi ke negeri Aceh itu pun datanglah mengadap Raja Merong Mahawangsa membawa surat dan bingkisan hadiah daripada raja Aceh itu, serta mengunjukkan surat itu dipersembahkan kepada baginda dengan segala bingkisan itu. Maka disuruh oleh Raja Merong Mahawangsa membaca surat itu pada menteri keempat. Setelah sudah dibacanya dan didengar oleh baginda sekalian yang tersebut di dalam surat itu, serta melihat segala bingkisan-bingkisan itu dengan berbagai aneka jenisnya daripada perbendaharaan perhiasan yang indah-indah, maka terlalulah sukacitanya ...

(Siti Hawa, 1998, p. 33)

[In the beginning, the emissary who had been instructed to go to Aceh had an audience with Raja Merong, delivering a letter and gifts from the king 
of Aceh. Raja Merong asked that the letter be read to the fourth minister. After the letter was read out and heard by his majesty who was mentioned in the letter, and having seen the wide variety of splendid gifts, his majesty was very pleased.]

The effect of maintaining the relationship, Langkasuka became a famous state. The proof is, when his son, Raja Merong Mahapudisat took over the reigns of government, Langkasuka's name was changed to Kedah Zamin Turan (Siti Hawa, 1998, p. 34) and it became a centre of attraction among foreigners, especially for traders. Its popularity was due to the leadership that was passed down to Raja Merong Mahapudisat as well as the existence of good relations with the governments of Aceh and Kelinggi. Traders were confident about the stability of the economy and the politics of Kedah. Therefore, they were not worried about choosing Kedah as their business destination. The result, economic activities and trade transactions increased and the people of Kedah lived in peace and harmony. According to Ann (2006, p. 8), among the effects of commercial transactions in a country, is the advancement of communication, interaction and interpersonal relations. Clearly, from the aspect of trading alone, this left a positive effect on the country.

\section{STRENGTHENING FAMILIAL RELATIONSHIPS BASED ONE TWO-IN-ONE APPROACH}

This method is carried out by using two dominant approaches towards a government or nation in order to achieve a goal. In this regard, the approaches taken were conferring awards and arranging marriages. Many times, Tuhfat an-Nafis mentions the use of these two approaches by Malay sultans in establishing diplomatic relations with the Bugis. The success achieved by the Bugis in the Malay Peninsula in helping a Malay leader ascend the throne attracted the attention of other Malay leaders to establish diplomatic relations with the Bugis. Among the successes achieved by the Bugis were aiding Sultan Muhammad Zainuddin, the king of Matan, to regain his throne which was seized by his brother Pangeran Agung ( Hooker, V.M, 1998, p. 61), helping Sultan Sulaiman Badrul Alam Syah (Raja Sulaiman) ascend the throne of Johor-Pahang-Riau as well as defeating the army of Raja Kecik (Hooker, V.M., 1998, p. 70) and returning the throne to the eldest king of Kedah (Hooker, V.M,1998, p. 84 ). 
In the manuscript, Tuhfat al-Nafis, it is said that the ruler of Sambas, Raja Adil used this approach to strengthen relations between Sambas and the Bugis. Raja Adil was of the opinion that his decision to establish diplomatic relations with the Bugis was the correct course of action. His majesty took the first step in approaching the Bugis king by sending a letter to Yang Dipertuan Muda (Opu Kelana Jaya Putera) inviting Bugis princes to come to Sambas. The contents of Raja Adil's letter openly stated his intention, that is to offer his relative by the name of Raden Tengah in marriage to one of them.

... kerana raja Sambas bernama Sultan Adil berkirim surat kepada Yang Dipertuan Muda, serta saudaranya, menyilakan (opu-opu itu) ke (negeri Sambas). Adalah maksudnya itu hendak didudukkannya dengan saudaranya salah seorang daripada opu(-opu) yang lima beradik (itu). Syahadan adapun opu-opu (yang lima beradik) itu masing (-masing) sudah ada ketetapannya (halnya), hanyalah Opu Dahing Kemasi sahaja yang belum tentu ketetapannya (dan belum ada rumah tangganya). Maka itulah sebab Opu Dahing Menambun (dibawanya) juga (paduka adinda baginda itu balik sebelah timur) demikianlah kisahnya.

(Hooker, V.M.,1998, p. 85)

[... because the ruler of Sambas, Raja Adil wrote a letter to Yang Dipertuan Muda, and his relatives, inviting the princes to Sambas. The intention was to arrange a marriage between his relative and one of the five sibling princes. However the five siblings already had commitments except Opu Dahing Kemasi. Hence Opu Dahing Menambun brought along his younger brother (Opu Dahing Kemasi) back to the east.]

The first approach involved marriage ties. Raja adil believed that marriage ties would be able to strengthen the relationship between governments. Raja Adil's initiative in marrying off his relative to Opu Dahing Kemasi succeeded in tying the Bugis to his kingdom. Therefore the Bugis influence spread into the administration which was what Raja Adil wanted. The implication was that the Sambas ruler grew even stronger in the Nusantara and foreign powers that wanted to destabilize the Sambas government had to abandon their intention because of these familial ties.

The second approach used by Raja Adil was conferring awards or recognition. In order to strengthen the relationship between the two governments, Raja Adil allowed Bugis involvement in his administration by appointing Opu Dahing Kemasi as Pangeran Mangkubumi. 
Syahadan tiada berapa (lamanya) antara maka sultan Sambas pun menikahkan Opu Dahing Kemasi dengan saudaranya yang bernama Raden Tengah, betapa adat istiadat raja besar-besar (ber)nikah kahwin demikianlah halnya. Kemudian (maka) Sultan Adil pun menggelar Opu Dahing Kemasi itu Pangeran Mangkabumi, memerintahkan kerajaan (negeri) Sambas di bawah sultan itu, demikianlah halnya (adanya).

(Hooker, V.M.,1998, p. 85)

[Not long after, the Sultan of Sambas married off his relative, Raden Tengah to Opu Dahing Kemasi, in a splendid royal wedding ceremony. Then, the Sultan bestowed the title Pangeran Mangkubumi on Opu Dahing Kemasi, who then helped the sultan to rule Sambas.]

Pangeran Mangkubumi is the title given to a pangeran who holds the post of prime minster (Mangkubumi). In peninsular Malaya, the tasks of Pangeran Mangkubumi are similar to those borne by a Bendahara. The duties of a Bendahara are similar to those of a Chief Minister or Prime Minister of today. Apart from that, the Bendahara also functions as the main adviser to the sultan and takes over the responsibility of the ruler when the latter is abroad (Muhammad Yusoff, 1992, p. 173). Opu Dahing Kemasi held the highest administrative post and had the right to make decisions as to where the government of Sambas was heading. In addition, this shows that the Bugis' political knowledge attracted the attention of the government of Sambas so that they involved the Bugis in their administration.

\section{DEVISING A CRAFTY PLAN}

Devising a crafty plan is an approach used by a government to counter various forms of threat. The main this approach is used is to alter the course, decision or perception of a government that has the intention of threatening another. In other words, this approach is also an initiative taken by a government to transform a negative situation into a positive one. Negative elements such as wars, if avoided will allow a state to develop and prosper. The act of avoiding wars or other threats is an act that leads to the settlement of a conflict (Mohamad Faisol and Mohammad Fuad, 2006, p. 111).

This approach as found in the manuscript was an episode about the government of Aceh wanting to attack and conquer Kedah to be part of its kingdom in order to expand its influence and power into the Malay peninsula. According to Pogadaev (2010, p. 183), at that time, the main focus of the 
Aceh people was to emulate Turkey which was well known as a big power. This intention of the ruler of Aceh, Sultan Iskandar was conveyed to Raja Menehara by Nakhoda Lamun who was a trader from Inderagiri trading in Kedah. Sultan Iskandar was a great ruler of Aceh and well known in the east and west (Ahmad Jelani, 2008, p. 292).

\section{Maka sahut Raja Menehara, "Nenda dapat khabar daripada Nakhoda Lamun bahawa Raja Aceh yang bernama Sultan Iskandar Mahkota Alam sudah bersiap angkatan peperangan hendak melanggar negeri Kedah ini. Barangkali tiada berapa lama lagi sampai-lah angkatan-nya itu ka-sini."}

(Mohd Zahid, 1968, p. 55)

[Then Raja Menahara said: "I was informed by Nakhoda Lamun that the ruler of Aceh by the name of Sultan Iskandar has his army ready to attack Kedah. Perhaps, before long, his army will be here.’]

When they heard the news, Kedah took steps to counter the threat. Two proposals were put forward to overcome this problem. The first proposal was that Sultan Sulaiman Shah (the Sultan of Kedah) should not surrender, instead make preparations to counter the attack. This meant that there would be an all-out war. Meanwhile a second proposal was presented by Dato' Seraja Imam who suggested that the government of Kedah refer to the "hundred and one conventions of war". Among the conventions were:

"Yang satu itu ia-lah berperang dengan tiada takut akan hilang nyawa-nya. Yang sa-ratus itu ia-lah dengan kira bichara dan ikhtiar. Sa-kira-nya tiada juga binasa seteru itu maka sampai-lah kapada yang satu isharat ia-itu berperang hingga terbuang nyawa.

(Mohd Zahid, 1968, p. 56)

["One convention is to take up arms without fear of loss of lives. One hundred refer to discussions and negotiations. If the enemy is not vanquished in this way, then fall back on the one, that is go to war until lives are lost.]

Other than that proposal, Dato' Seraja Imam also advised Sultan Sulaiman to solve the problem through diplomacy.

"Ampun tuanku, jikalau boleh lagi kita ikhtiarkan dengan jalan yang lain salain daripada berperang itu terlebeh baiklah daripada kita berperang kerana 
tiada terlebeh jahat patek2 sakalian membawa Shah Alam kapada pekerjaan perang, kerana banyak lagi yang dapat di-lakukan sa-lain daripada pekerjaan perang itu, ia-itu saperti dengan ikhtiar atau dengan harta. Jika tiada dapat di-tolakkan dengan ikhtiar yang demikian itu, tatkala itu berperang-lah kita. Apakala terjadi peperangan tiada dapat lagi di-bicharakan dengan harta melainkan dengan nyawa juga."

(Mohd Zahid, 1968, p.56)

[Your Majesty, if possible, think of other ways than going to war, it is better not to go to war, there is nothing worse than bringing Shah Alam into war, as there are many other ways such as negotiation or property. If negotiation does not work, then we take up arms. Once war breaks out, there is no more room for negotiation with property, then we will have to do it with our lives.]

According to Jelani (2003, p. 14), the one hundred and one conventions suggested by Dato' Seraja Imam was his effort to avoid war. He appealed to the sultan not to bring Kedah and the sultan himself into armed conflict. Every war that takes place will definitely incur many negative effects onto a state, for example destruction of property and loss of lives of the people. Hence Dato' Seraja Imam proposed to Sultan Sulaiman that a crafty plan be devised instead. The proposed plan included:

(a) Staging a big welcome for Sultan Iskandar with full ceremonial honours in the manner of a welcome fit for kings of friendly states.

(b) Preparing a fully decorated palace for the sultan of Aceh and his army.

This crafty plan of Dato' Seraja Imam is evident in this following excerpt:

Maka sembah Dato'Seraja Imam, "Pada pendapat patek hamba ini, baik-lah kita chuba sambut kedatangan angkatan musoh itu dengan chukup isharat kehormatan seperti menyambut angkatan kedatangan raja yang besar 2 yang menziarah negeri ini, dan kita siapkan suatu istana chukup dengan perhiasan, dan kita hiaskan kenaikan bagi menyambut-nya di-laut dan kenaikan pada pehak darat."

(Mohd Zahid, 1968, p. 57)

[Dato' Seraja Imam said: “ In my humble opinion, let us try to welcome the arrival of the enemy forces with full honours in the manner of a welcome fit for mighty kings who visit this kingdom, and we prepare a fully decorated palace, and decorate the vehicles to welcome them at sea and at land."] 
This plan was approved by the sultan and he ordered his ministers to make preparations immediately. In this matter, the wisdom of Dato' Seraja Imam reflected the wisdom of Kedah officials which was recorded by the author of this manuscript. Jelani (2003, p. 15) is of the view that this advice by Dato' Seraja Imam was a wise effort to avoid going to war with Aceh, considering that Aceh at that time was a superior power in the Malay world. Apart from that, this crafty plan is in line with Hassan's opinion that is, it is better to avoid the possibility of war rather than wait until the enemy becomes a formidable one.

This plan was effective since Sultan Iskandar reacted positively. He was moved by the gestures to the extent of canceling his intention to attack and instead he accepted Kedah's invitation to welcome him to Sultan Sulaiman's palace. The following excerpt demonstrates this:

Welcoming guests:

Maka Tengku Rijaluddin dengan menteri2-nya pun naik dudok menyembah. Satelah dudok berkata 2 sa-ketika maka dipersembahkan surat paduka ayahanda baginda itu serta dima'alumkan dengan perkataan yang elok susun-nya dan halus manis, mempersilakan Sultan Iskandar Mahkota Alam masok ka-negeri.

(Mohd Zahid, 1968, p. 62)

[Hence, Tengku Rijaluddin and his ministers went up and paid obeisance to the sultan. After sitting down he presented a letter from his father and he informed the sultan in a nicely worded invitation, that the Sultan was welcome to enter the state.]

Method of Implementation (2): Having an audience with the sultan of Kedah.

Maka pada ketika itu Tengku Paduka Maharaja Temenggong Anggota Desa dengan sekalian hulubalang pahlawan memberi hormat, lalu dimain nobat nafiri terlalu gemuroh bunyi-nya. Lalu dipersilakan masok oleh Tengku Paduka Maharaja Temenggong akan Sultan Iskandar Mahkota Alam dan sakalian pengiring-nya, langsong mereka itu ka-hadapan balai dan di-sambut oleh Dato; Seri Maharaja Putra Dewa lalu naik ka-balai. Pada ketika itu Sultan Sulaiman Shah Yang Maha Mulia ada hadhir menanti di-balai penghadapan, lalu hormat berhormat-lah kedua 2 sultan itu, lalu dudok di atas singgahsana dihadap oleh paduka anakanda baginda Tengku Rijaluddin dan segala menteri2.

(Mohd Zahid, 1968, p. 62) 
[At that time, Tengku Paduka Maharaja Temenggong Anggota Desa with all his soldiers stood at attention, and the court music was played loudly. Then, Tengku Paduka Maharaja Temenggong Anggota Desa invited Sultan Iskandar and his entourage to enter. They all went into the reception hall and were greeted by Dato' Seri Maharaja Putra Dewa who led them up to the hall. At that moment, Sultan Sulaiman was there waiting for them in the audience hall, the two rulers then showed respect to each other, and sat on the throne, and were waited upon by the Sultan's son, Tengku Rijaluddin and all the ministers.]

In the meantime, Sultan Iskandar reacted in these ways towards the government of Kedah after the welcoming ceremony.

The sultan was moved:

Pada ketika itu layu-lah hati Sultan Iskandar hendak meneruskan maksud-nya (Mohd Zahid, 1968:62)

[At that time, Sultan Iskandar was extremely moved and was thus reluctant to carry out his intentions.]

\section{Reaction Effect:}

Maka Sultan Iskandar dengan segala hulubalang-nya sangat hairan serta malu yang amat sangat melihat menteri2 hulubalang pahlawan yang tertib lendit peratoran mereka di-balai penghadapan itu.

(Mohd Zahid, 1968, p. 63)

[Sultan Iskandar with all his soldiers were surprised and touched seeing how respectful the ministers and soldiers were in the audience hall.]

Acceptance Reaction:

Pada ketika itu luput-lah maksud di-hati Sultan Iskandar Mahkota Alam hendak mengambil negeri Kedah, serta Sultan Iskandar pun beraleh hati-nya kapada berkaseh2an dengan Sultan Sulaiman Shah seperti saudara-nya sendiri.

(Mohd Zahid, 1968, p. 63)

[At that time, Sultan Iskandar did not have the heart to conquer Kedah, instead he treated Sultan Sulaiman with warmth and friendliness as if they were kins.] 
The effect of the initiative by the ministers and the sultan of Kedah was that the government of Kedah finally managed to overturn Aceh's intentions. The approach taken by Kedah in this crafty plan is something that should be emulated by other Malay governments in order to avoid wars and form new diplomatic relations with influential nations. Thus the relationship between Aceh and Kedah became even closer when the sultan of Kedah accepted the sultan of Aceh's invitation to go back to Aceh with him.

Maka kata Sultan Iskandar, "Kakanda ingat dalam lima enam hari lagi hendak berangkat balek ka-Aceh. Kakanda sangat2 berharap dan berbesar hati kalau adinda dapat bersama2 kakanda pergi bermain2 di-negeri Acheh barang sa-bulan dua." Maka di-bukakan Allah Subhanahu wa-Ta'ala hati Sultan Sulaiman Shah dan baginda suka hendak pergi melihat negeri Acheh dan lain2 negeri itu. Maka pada ketika itu di-kabulkan maksud Sultan Iskandar itu. Maka Sultan Iskandar Shah pun sangat suka hati-nya.

(Mohd Zahid, 1968, p. 65)

[Said Sultan Iskandar: "I think in five or six days time I would like to return to Aceh. I really hope and would be very pleased if you return with me and have a pleasant time in Aceh for a month or two." Allah SWT instilled in Sultan Sulaiman Shah a desire to see Aceh and other states. It was at that particular moment that he acceded to Sultan Iskandar's request. Which pleased Sultan Iskandar Shah a great deal.]

The crafty plan devised by the Kedah government was successful because of the cooperation and wisdom of the Kedah ruler and Malay officials, the result of which an enemy state became non-threatening. The threat of war can be avoided if both sides desire peace and focus on diplomatic goals. According to Zulhilmi and Asrar (2003, p. 36), peaceful overture is an approach often used to deal with diplomatic and international conflicts.

\section{CONCLUSION}

The leadership of the Malay sultanate in establishing diplomatic relations demonstrates the intellectualism of the leaders in utilizing various methods to ensure that diplomatic relations take place smoothly. In addition, this leadership is important in protecting and defending the integrity of the nation. The findings of this study reveal that there were four methods used: (a) that of sending envoys/emissaries of high calibre (b) that of establishing 
diplomatic relations with two governments simultaneously, (c) that of strengthening familial relationships based on a two-in-one approach and (d) that of devising a crafty plan. All four methods were carried out in the diplomatic events described in Malay historiographical manuscripts; Sulalat al-Salatin, Al-Tarikh Salasilah Negeri Kedah, Hikayat Merong Mahawangsa and Tuhfat al-Nafis. The method of sending high-calibre emissaries are represented in Sulalat al-Salatin, that of establishing diplomatic relations with two governments simultaneously are represented in Hikayat Merong Mahawangsa, Tuhfat al-Nafis recounts strengthening familial relationships based on two-in-one approach and crafty planning.

Every successful initiative by the Malay leadership in carrying out diplomatic relations is akin to giving new life to the government. The loose aspects in a government can be covered by establishing diplomatic relations. This means that the collaboration between two or more governments will fortify the administration of the individual governments. Therein lies the importance of having a government whose leaders possess leadership especially in matters of diplomatic relations.

\section{REFERENCES}

Abdullah Hassan \& Ainon Mohd. (2005). Kemahiran interpersonal untuk guru. Kuala Lumpur: PTS Publications \& Distributor Sdn. Bhd.

Abdur-Rahman Mohamed Amin. (2015). Sabda Nabi Muhammad SAW dalam Sulalat us-Salatin. Melayu: Jurnal Antarabangsa Dunia Melayu, 8 (1), 45-62.

Abu Hassan Sham. (2001). Bahasa, kesusasteraan, kesenian, proses sosialisasi dan pembudayaan masyarakat Melayu. Tamadun Islam dan Tamadun Asia. Mohd Taib Osman (ed.). Kuala Lumpur: Penerbit Universiti Malaya.

Ahmad Jelani Halimi. (2008). Sejarah dan tamadun bangsa Melayu. Kuala Lumpur: Utusan Publications \& Distributors.

Arbai'yah Mohd Noor. (2014). Menelusuri nilai etika dalam pemerintahan JohorRiau-Lingga menerusi naskhah Tuhfat al- Nafis versi Terengganu. Prosiding naskhah dan relevasinya dalam kehidupan masa kini. Yumi Sugahara (ed.). (pp. 165-185). Universitas Andalas: Pusat Studi dan Informasi Kebudayaan Minangkabau.

A. Samad Ahmad (comp.). (2010). Sulalatus Salatin: Sejarah Melayu (Edisi

Kesepuluh). Kuala Lumpur: Dewan Bahasa dan Pustaka.

Bustan al-Salatin (Universiti Malaya, MS 41).

Gallop, Annabel Teh. (1994). Warisan warkah Melayu. London: The British Library. 
Hooker, Virgina Matheson (comp.). (1998). Tuhfat al-Nafis. Kuala Lumpur: Yayasan Karyawan dan Dewan Bahasa dan Pustaka.

Jelani Harun. (2003). Pemikiran adab ketatanegaraan Kesultanan Melayu. Kuala Lumpur: Dewan Bahasa dan Pustaka.

Jelani Harun. (2009). Bustan al-Salatin: A Malay mirror for rulers. Pulau Pinang: Penerbit Universiti Sains Malaysia.

Mahani Musa. (2015). The memory of the world register: The Sultan Abdul Hamid correspondence and Kedah history. Kajian Malaysia, 33(2), 53-74.

Mohamad Faisol Keling \& Mohammad Fuad Othman. (2006). Pengajian strategi ilmu sebagai disiplin. Kuala Lumpur: Utusan Publication \& Distributors.

Mohamed Nazreen Shahul Hamid \& Md. Salleh Yaapar. (2015). Adaptasi teks Hikayat Merong Mahawangsa kepada filem: Analisis perbandingan unsur naratif. Melayu: Jurnal Antarabangsa Dunia Melayu, 8 (1), 201- 223.

Mohd Azhar Abdul Hamid. (2004). EQ : Panduan meningkatkan Kecerdasan Emosi. Batu Caves: PTS Publications \& Distributors.

Mohd Zahid bin Mohd Shah (eds.). (1968). Al-Tarikh Salasilah Negeri Kedah. Kuala Lumpur: Dewan Bahasa dan Pustaka.

Mokhtar Muhammad. (2005). Perhubungan antarabangsa: Konsep dan konteks. Kuala Lumpur: Anzagain Sdn. Bhd.

Muhammad Yusoff Hashim. (1992). Pensejarahan Melayu: Kajian tentang tradisi sejarah Melayu Nusantara. Kuala Lumpur: Dewan Bahasa dan Pustaka dan Kementerian Pendidikan Malaysia

Nasihat al-Muluk (SOAS, Universiti London, MS 4639)

Northouse, Peter Guy. (1997). Leadership: theory and practice. Thousand Oaks, Calif: Sage Publications.

Pogadaev, Victor A. (2010). Perjuangan Kesultanan Aceh mempertahankan kemerdekaannya: Diplomasi sulit dan politik intrik. Jurnal Terjemahan Alam \& Tamadun Melayu, 2(1), 182-193.

Salmah Jan. (2015). Warkah sebagai medium diplomatik Kesultanan Melayu dalam menjalankan hubungan dengan kuasa Barat. Jurnal Melayu, 14 (1), 136- 148.

Siti Hawa Salleh (comp.). (1998). Hikayat Merong Mahawangsa. Kuala Lumpur: Yayasan Karyawan dan Penerbit Universiti Malaya.

Zulhilmi Paidi \& Asrar Omar (eds.). 2003. Hubungan luar antarabangsa. Bentong: PTS Publication \& Distributors Sdn. Bhd.

Received: 16 August 2017

Accepted: 25 September 2017 